University of Nebraska - Lincoln

DigitalCommons@University of Nebraska - Lincoln

Papers in Plant Pathology

Plant Pathology Department

August 2000

\title{
A plant virus vector for systemic expression of foreign genes in cereals
}

II-Ryong Choi

University of Nebraska-Lincoln

Drake C. Stenger

University of Nebraska-Lincoln

Thomas Jack Morris

University of Nebraska-Lincoln, jmorris1@unl.edu

Roy C. French

University of Nebraska-Lincoln, rfrench2@unl.edu

Follow this and additional works at: https://digitalcommons.unl.edu/plantpathpapers

Part of the Plant Pathology Commons

Choi, Il-Ryong; Stenger, Drake C.; Morris, Thomas Jack; and French, Roy C., "A plant virus vector for systemic expression of foreign genes in cereals" (2000). Papers in Plant Pathology. 24.

https://digitalcommons.unl.edu/plantpathpapers/24

This Article is brought to you for free and open access by the Plant Pathology Department at DigitalCommons@University of Nebraska - Lincoln. It has been accepted for inclusion in Papers in Plant Pathology by an authorized administrator of DigitalCommons@University of Nebraska - Lincoln. 


\title{
A plant virus vector for systemic expression of foreign genes in cereals
}

\author{
II-Ryong Choi ${ }^{1}$, Drake C. Stenger ${ }^{2}$, T. Jack Morris ${ }^{1}$ and Roy French ${ }^{2, *}$ \\ ${ }^{1}$ School of Biological Sciences and \\ ${ }^{2}$ USDA-ARS, 344 Keim Hall, University of Nebraska, Lincoln, NE 68583, USA \\ Received 15 February 2000; revised 24 May 2000; accepted 24 May 2000. \\ *For correspondence (fax +1 402472 2853; e-mail rfrench@unlnotes.unl.edu).
}

\begin{abstract}
Summary
Inserts bearing the coding sequences of NPT II and $\beta$-glucuronidase (GUS) were placed between the nuclear inclusion b (Nlb) and coat protein (CP) domains of the wheat streak mosaic virus (WSMV) polyprotein ORF. The WSMV NIb-CP junction containing the nuclear inclusion a (Nla) protease cleavage site was duplicated, permitting excision of foreign protein domains from the viral polyprotein. Wheat, barley, oat and maize seedlings supported systemic infection of WSMV bearing NPT II. The NPT II insert was stable for at least 18-30 days post-inoculation and had little effect on WSMV CP accumulation. Histochemical assays indicated the presence of functional GUS protein in systemically infected wheat and barley plants inoculated with WSMV bearing GUS. The GUS constructs had greatly reduced virulence on both oat and maize. RT-PCR indicated that the GUS insert was subject to deletion, particularly when expressed as a GUS-NIb protein fusion. Both reporter genes were expressed in wheat roots at levels comparable to those observed in leaves. These results clearly demonstrate the utility of WSMV as a transient gene expression vector for grass species, including two important grain crops, wheat and maize. The results further indicate that both host species and the nature of inserted sequences affect the stability and expression of foreign genes delivered by engineered virus genomes.
\end{abstract}

Keywords: virus gene expression vector, cereals, monocotyledonous plants.

Introduction

Several viruses infecting dicotyledonous plants have been modified to express foreign genes. Uses of plant virus gene vectors include interferon production (De Zoeten et al., 1989), antigen display (Fitchen et al., 1995; Joelson etal., 1997; Koo etal., 1999; Porta etal., 1994; Sugiyama et al., 1995; Turpen etal., 1995; Usha etal., 1993; Wigdorovitz etal., 1999; Yusibov etal., 1997), antibody production (McCormick etal., 1999; Verch etal., 1998), virus movement assays with reporter genes (Angell and Baulcombe, 1995; Baulcombe et al., 1995; Casper and Holt, 1996; Chapman etal., 1992; Dolja etal., 1992; Scholthof etal., 1993), gene silencing (Angell and Baulcombe, 1999; Baulcombe, 1999; Ruiz etal., 1998), alteration of biochemical pathways (Kumagi etal., 1993; Kumagi etal., 1995; Kumagi etal., 1998), functional characterization of pathogen avirulence genes and host resistance genes

(C) 2000 Blackwell Science Ltd
(Hammond-Kosack etal., 1995; Rommens etal., 1995; Tobais etal., 1999), and various gain-of-function assays (Baulcombe et al., 1993; Karrer etal., 1998; Ryabov et al., 1998; Scholthof et al., 1995; Whitham et al., 1999). Insert instability and loss of systemic movement were recurrent problems requiring significant effort for their solution, as exemplified in studies with gene vectors based on tobacco mosaic virus (TMV) (Culver et al., 1993; Dawson et al., 1989; Donson etal., 1991; Hamamoto etal., 1993; Kearney etal., 1993; Shivprasad etal., 1999; Takamatsu et al., 1990).

Despite these advances, there is currently no suitable virus vector for systemic expression of foreign genes in monocotyledonous plants. Two modified RNA plant viruses, brome mosaic virus (BMV) (French et al., 1986) and barley stripe mosaic virus (BSMV) (Joshi etal., 1990), efficiently express reporter genes in monocotyledonous 
(a)

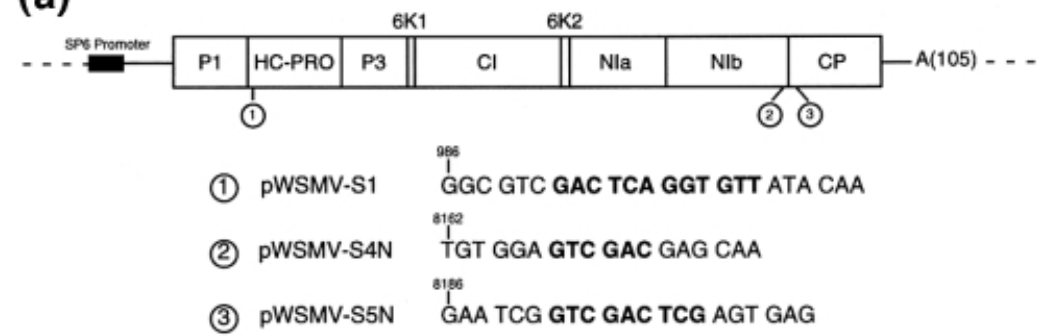

(b)

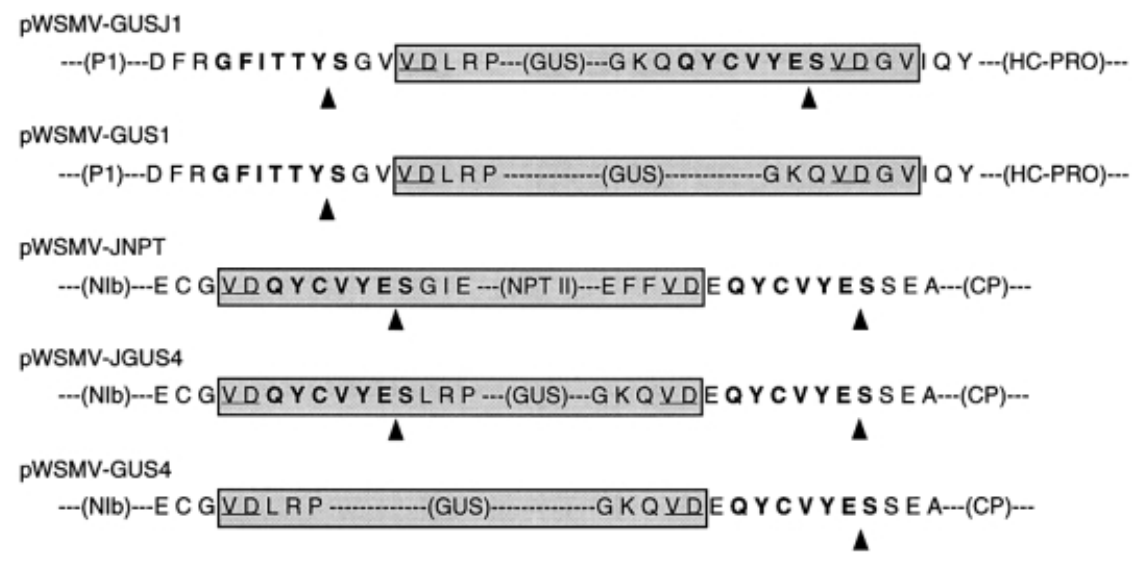

Figure 1. Construction of WSMV gene vectors.

(a) Positions $(1,2,3)$ in the WSMV genome selected for insertion of 6-12 nucleotides (bold) containing engineered Sall cleavage sites (GTCGAC) in constructs pWSMV-S1, pWSMV-S4N and pWSMV-S5N. (b) WSMV gene vector constructs bearing foreign sequences (shaded boxes) inserted at position 1 (pWSMV-GUSJ1 and pWSMVGUS1) or position 2 (pWSMV-JNPT, pWSMV-JGUS4 and pWSMV-GUS4). Predicted viral protease cleavage sites are in bold with arrows denoting the location of the cleaved peptide bond. Underlined amino acids (VD) denote amino acid residues encoded by the inserted Sall recognition sequence. Additional amino acid residues remaining at the $\mathrm{N}$ - or $\mathrm{C}$-termini of reporter proteins after proteolytic processing and not present in native NPT II or GUS proteins are identified. Constructs pWSMV-JGUS1, pWSMV-JNPT and pWSMV-JGUS4 have viral protease cleavage sites flanking the reporter gene such that the foreign protein is completely excised from the viral polyprotein. Constructs with only a single protease cleavage site adjacent to the foreign protein result in fusion proteins where GUS remains as a C-terminal fusion with the NIb protein (pWSMV-GUS4) or as an $\mathrm{N}$-terminal fusion with the $\mathrm{HC}$-Pro protein (pWSMV-GUS1). plant cells but do not move systemically in whole plants. Similarly, modified DNA genomes of the geminiviruses wheat dwarf virus and maize streak virus express foreign genes in monocotyledonous plant cells (Laufs etal., 1990; Lazarowitz et al., 1989; Matzeit et al., 1991; Palmer etal., 1999; Shen and Hohn, 1994; Shen and Hohn, 1995; Timmermans etal., 1992; Ugaki etal., 1991), but likewise fail to spread systemically.

The single ORF of bamboo mosaic virus satellite RNA (satBaMV) may be replaced to express a foreign gene when co-inoculated with its helper virus into Chenopodium quinoa (Lin etal., 1996). Unfortunately, satBaMV and its helper virus have a narrow host range which includes only two monocotyledonous species (bamboo and barley). Although a foreign gene product delivered to barley by satBaMV was detected in systemically infected leaves, the level of expression was only 1/40th to $1 / 100$ th of that in inoculated leaves (Lin et al., 1996).

Given the limitations of existing viral vectors to express foreign genes in monocotyledonous plants, we examined the potential of wheat streak mosaic virus (WSMV) as a gene vector. WSMV infects many grasses, including several key cereal crop species, and is readily mechanically transmissible. Recently, an infectious clone of WSMV has been constructed (Choi et al., 1999), so that experiments to insert foreign sequences into the WSMV genome are now feasible. WSMV is the type member of the newly recognized genus Tritimovirus, with a genome organization typical of the family Potyviridae (Stenger et al., 1998). We reasoned that the WSMV genome could be modified to accept foreign genes in a fashion similar to that demonstrated for the potyvirus, tobacco etch virus (TEV) (Dolja etal., 1992; Dolja etal., 1997; Dolja etal., 1998; Whitham et al., 1999). In this report, we describe the development of a WSMV-based gene vector capable of systemic expression of foreign genes in wheat and other cereals.

\section{Results}

\section{Genomic location for insertion of foreign genes in WSMV}

Three positions in the WSMV genome were targeted to accept foreign sequences by the insertion of a Sall cleavage site (Figure 1a). Position 1 is immediately downstream of the predicted cis cleavage site of the P1 protein for excision from the viral polyprotein, and is the analogous position used in gene vectors based on TEV (Dolja etal., 1992). Position 2 is located immediately upstream of the nuclear inclusiona (Nla) protease cleavage site at the nuclear inclusion $\mathrm{b}(\mathrm{NIb})$-coat protein (CP) junction, whereas position 3 is located immediately downstream of this same proteinase cleavage site (Figure 1a). RNAs transcribed from pWSMV-S1, pWSMV- 
S4N, and pWSMV-S5N (containing Sall insertions at positions 1,2 and 3 , respectively) were inoculated onto wheat seedlings. RNA transcripts of pWSMV-S1 and pWSMV-S4N were infectious and produced systemic symptoms resembling those of wild-type RNA transcripts of pACYC-WSMV (Choi etal., 1999), whereas RNA transcribed from pWSMV-S5N was not infectious (data not shown). Although the WSMV genome tolerated the small Sall insert at position 1, attempts to insert $\beta$-glucuronidase (GUS) sequences (constructs pWSMV-GUSJ1 and pWSMVGUS1) did not yield infectious transcripts (data not shown). Therefore, the WSMV gene vector constructs pWSMVJNPT, pWSMV-JGUS4 and pWSMV-GUS4 (Figure 1b) described below used pWSMV-S4N as the cloning vector for insertion of foreign gene sequences.

\section{NPT II expression in cereals}

Wheat seedlings inoculated with RNA transcribed from pWSMV-JNPT expressed detectable NPTII protein (Figure 2a) as early as 6 days post-inoculation (dpi). Accumulation of NPT II protein in wheat peaked at $12 \mathrm{dpi}$ (averaging $238 \mathrm{ng} \mathrm{mg}^{-1}$ soluble protein, or about $11 \mu \mathrm{g} \mathrm{g}^{-1}$ fresh leaf tissue), and by $18 \mathrm{dpi}$ the amount of NPT II protein detected in infected wheat plants was reduced slightly to an average of $204 \mathrm{ng} \mathrm{mg}^{-1}$ soluble protein. The highest NPT II protein level observed in a single wheat plant extract was approximately $300 \mathrm{ng} \mathrm{mg}^{-1}$ soluble protein, or $14 \mu \mathrm{g} \mathrm{g}^{-1}$ leaf tissue. Barley, oat and maize seedlings inoculated with RNA transcribed from pWSMV-JNPT and assayed 3-7 days after the appearance of systemic symptoms also produced substantial amounts of NPTII protein (Figure 2b). Barley and oat plants contained levels of NPT II protein (averages of 176 and $201 \mathrm{ng} \mathrm{mg}^{-1}$ soluble protein, respectively) that were about the same as that observed in wheat, whereas in maize (averaging $78 \mathrm{ng} \mathrm{mg}^{-1}$ soluble protein) the level of NPT II protein accumulation was about $40 \%$ of that found in the other cereals.

NPT II protein, produced in wheat inoculated with RNA transcribed from pWSMV-JNPT, migrated in a polyacrylamide gel slightly more slowly than the commercially prepared and purified NPT II protein standard (Figure 3a). No NPT II protein was detected in uninoculated plants or in plants inoculated with wild-type WSMV (pACYC-WSMV) or WSMV bearing only the introduced Sall cloning site (pWSMV-S4N). The N- and C-terminal residues of NPTII protein encoded by pWSMV-JNPT transcripts are different from those of the native protein. NPTII produced by pWSMV-JNPT is predicted to have serine replacing methionine at the $\mathrm{N}$-terminus and nine additional C-terminal amino acid residues not present in native NPT II protein (Figure 1b). Thus, the slightly reduced electrophoretic mobility of NPTII protein produced in plants infected with pWSMV-JNPT transcripts was (a)

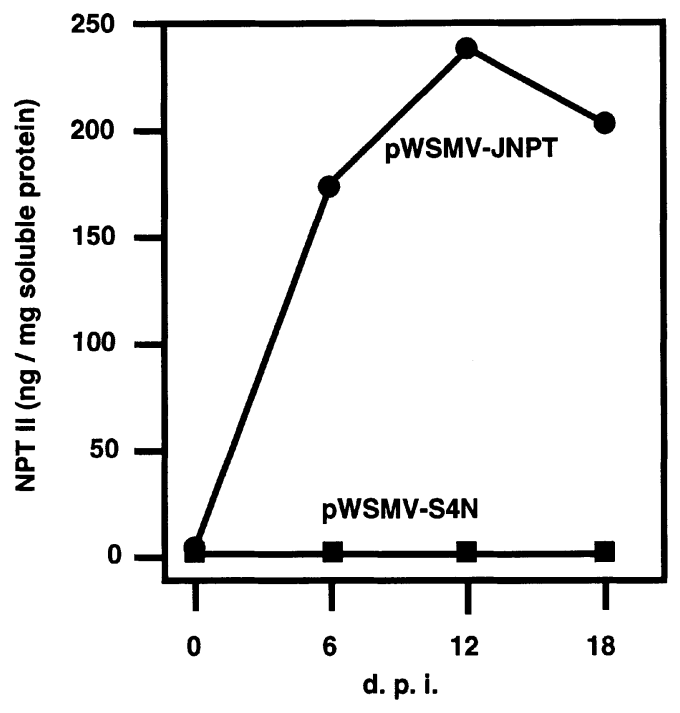

(b)

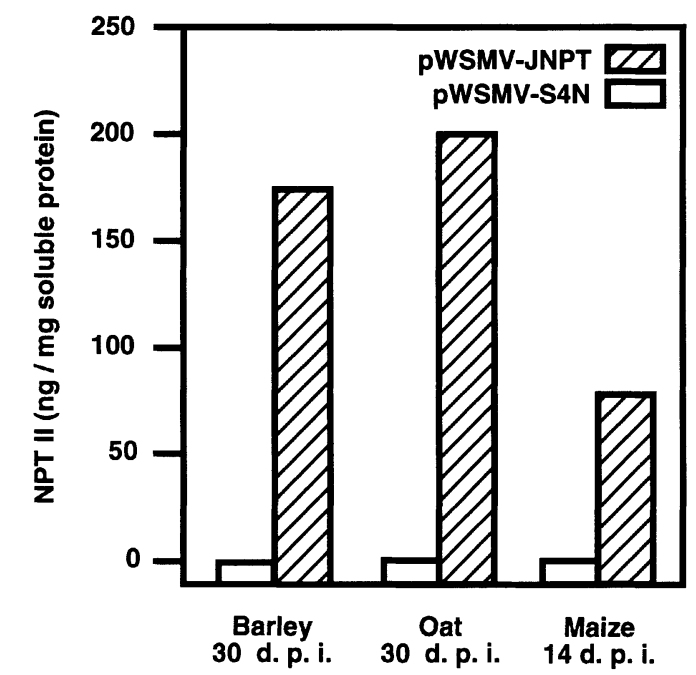

Figure 2. Accumulation of NPT II protein in plants systemically infected with WSMV bearing (pWSMV-JNPT) or lacking (pWSMV-S4N) the NPTII gene.

(a) Accumulation of NPTII protein in soluble protein samples extracted from wheat plants $0,6,12$ and 18 days post inoculation (dpi). (b) Accumulation of NPT II protein in soluble protein samples extracted from barley, oats and maize at a single time point 3-7 days after the appearance of systemic symptoms. Concentration of NPTII protein present in soluble protein samples was determined by ELISA using commercially prepared and purified NPTII protein as a standard. NPT II concentrations presented are the mean of three plants sampled for each treatment

expected, and indicates that the WSMV Nla protease cleavage sites flanking NPT II sequences in pWSMV-JNPT were recognized and cleaved by Nla to release the foreign protein domain from the viral polyprotein.

Stability of the virus gene vector derived from pWSMVJNPT was investigated by RT-PCR of total RNA samples 

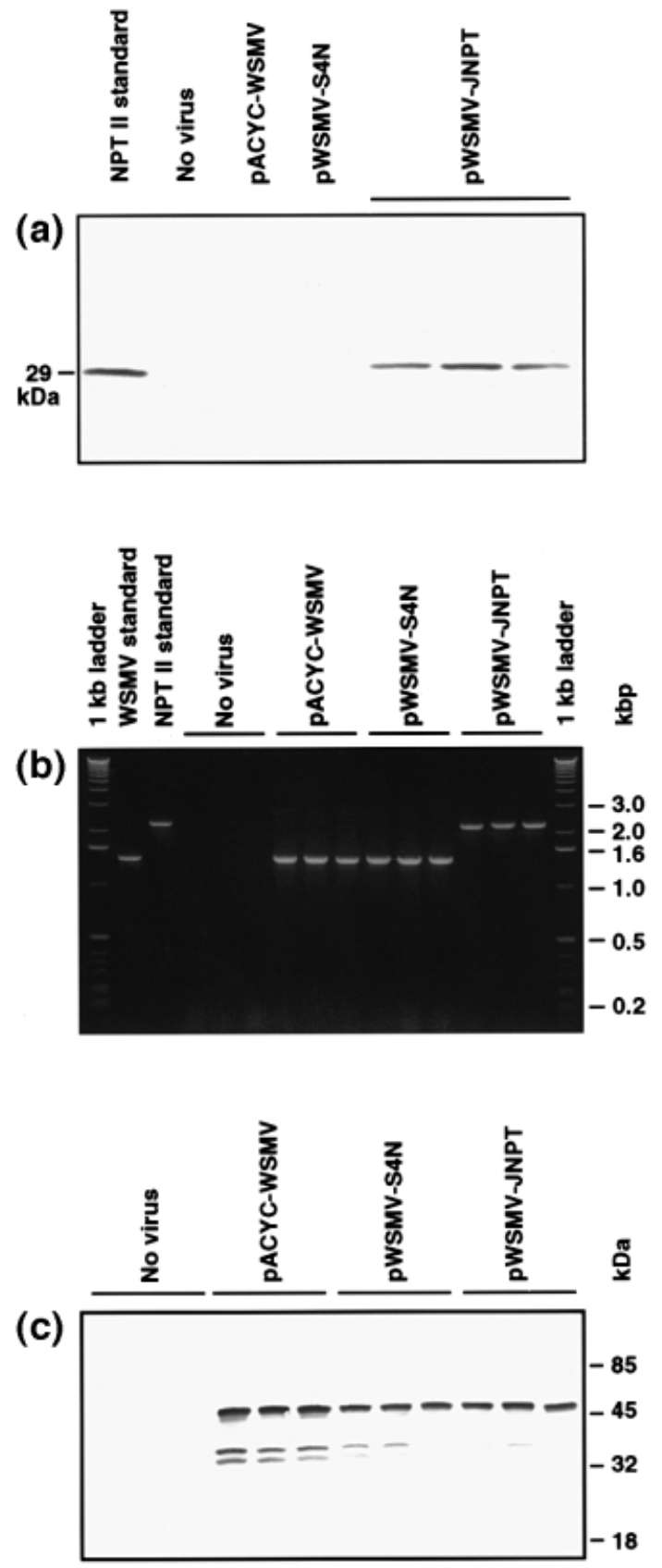

Figure 3. Analysis of wheat plants systemically infected with WSMV bearing or lacking the NPTII gene.

Wheat seedlings were inoculated with RNA transcribed from pACYCWSMV (wild-type), pWSMV-S4N (WSMV modified to contain a Sall site at the NIb-CP junction) or pWSMV-JNPT (WSMV bearing the NPTII coding sequence flanked by Nla protease cleavage sites and inserted into pWSMV-S4N). The 'no virus' treatment represents extracts from uninoculated wheat plants. (a) An immunoblot of total soluble protein samples extracted from wheat and probed with NPTII antibody. The NPTII standard $(29 \mathrm{kDa})$ is commercially prepared and purified NPTII protein. (b) RT-PCR of RNA samples extracted from wheat plants 18 days post-inoculation. WSMV and NPTII standards represent PCR products derived from pACYC-WSMV and pWSMV-JNPT plasmid DNA templates, respectively. The sizes $(\mathrm{kbp})$ of $1 \mathrm{~kb}$ ladder DNA standards are indicated on the right. (c) An immunoblot of total soluble protein samples extracted from wheat and probed with WSMV CP antibody. The sizes $(\mathrm{kDa})$ and mobilities of protein standards are indicated on the right. from wheat extracted $18 \mathrm{dpi}$ (Figure 3b). RT-PCR of pWSMV-JNPT-infected wheat consistently yielded a product identical in size to a PCR product derived from pWSMV-JNPT plasmid DNA, indicating that the viral vector retained NPTII sequences upon systemic infection. RT-PCR analysis of samples extracted from wheat 6 and $12 \mathrm{dpi}$ yielded the same products (data not shown) as at $18 \mathrm{dpi}$. Importantly, barley and oat plants infected with pWSMV-JNPT continued to produce NPTII protein at $30 \mathrm{dpi}$ (Figure 2b).

The effect of inserted NPTII sequences on viral gene expression was assessed by immunoblotting of the WSMV $\mathrm{CP}$ (Figure 3c). Accumulation of WSMV CP in wheat plants $18 \mathrm{dpi}$ with RNA transcribed from pWSMV-JNPT was only slightly less than for wild-type WSMV, and was essentially the same as for WSMV bearing the engineered Sall site. Wheat plants extracted 6 and 12 dpi (data not shown) gave similar results.

\section{GUS expression in cereals}

A time-course study in wheat (Figure 4a) demonstrated the presence of functional GUS protein in plants inoculated with RNA transcripts of WSMV modified either to express GUS as a fusion protein with NIb (pWSMV-GUS4), or bearing GUS flanked by Nla cleavage sites for its complete excision from the viral polyprotein (pWSMV-JGUS4). Histochemical staining revealed that pWSMV-JGUS4 expressed GUS earlier and produced higher levels of functional GUS protein than did pWSMV-GUS4. This suggested that expression was more efficient when GUS was cleanly excised from the viral polyprotein, rather than remaining fused to the C-terminus of the $\mathrm{NIb}$ protein. Interestingly the spatial pattern of GUS expression mimicked the typical yellow-green mosaic symptoms of WSMV infection in wheat.

Expression of functional GUS protein in other cereal species was evaluated by histochemical staining (Figure 4b). Barley supported systemic expression of functional GUS protein $15 \mathrm{dpi}$ with the pWSMV-JGUS4 gene vector. In contrast, GUS expression in oat was limited to clusters of cells at infection foci detected $3 \mathrm{dpi}$ (Figure 4b). No GUS activity was detected in oat leaves assayed at $9 \mathrm{dpi}$ (data not shown), indicating that GUS expression was both localized and transitory in this host. In maize, GUS activity was not observed at any time postinoculation with pWSMV-JGUS4 (Figure 4b and data not shown).

Unlike the NPTII-bearing constructs, WSMV gene vectors bearing GUS tended to be unstable. RT-PCR analysis indicated that the accumulation of GUS sequences in wheat was both delayed and reduced for pWSMVGUS4 relative to pWSMV-JGUS4 (Figure 5a). Furthermore, less than full-length RT-PCR products were observed for 
(a)
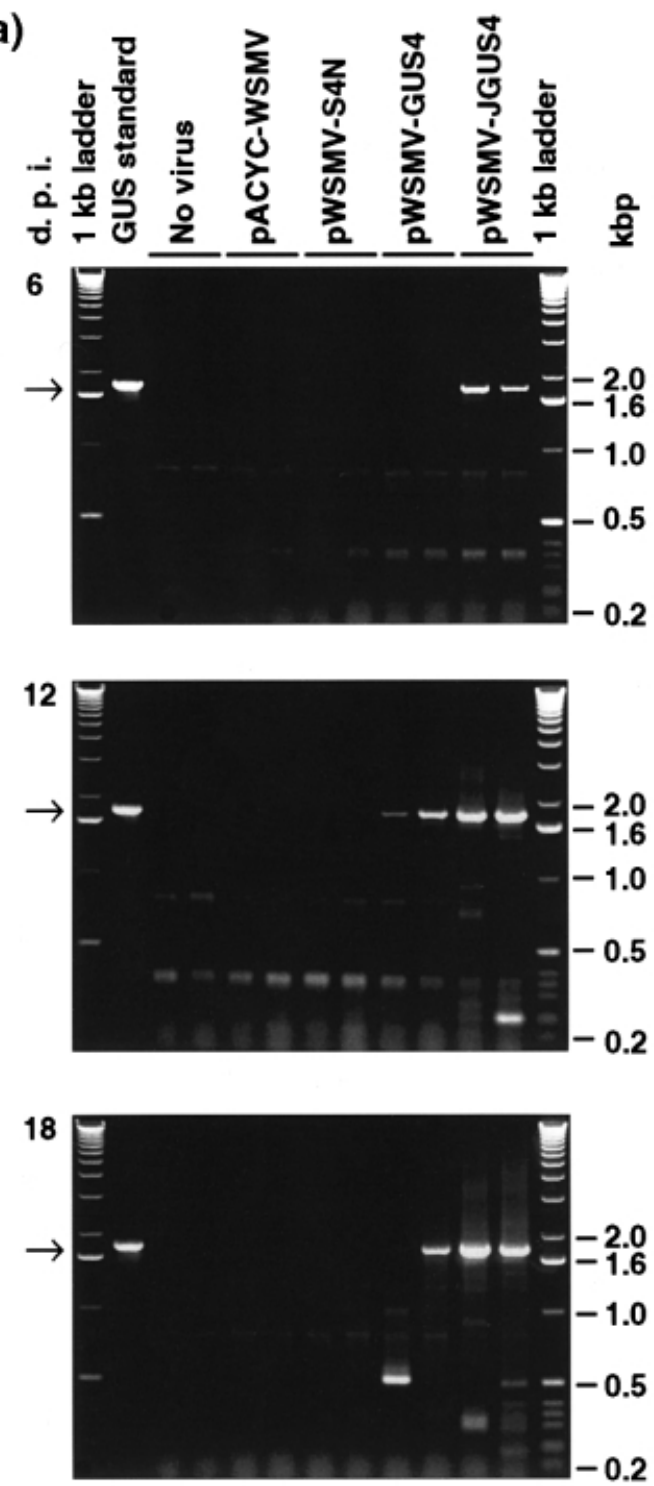

(b)

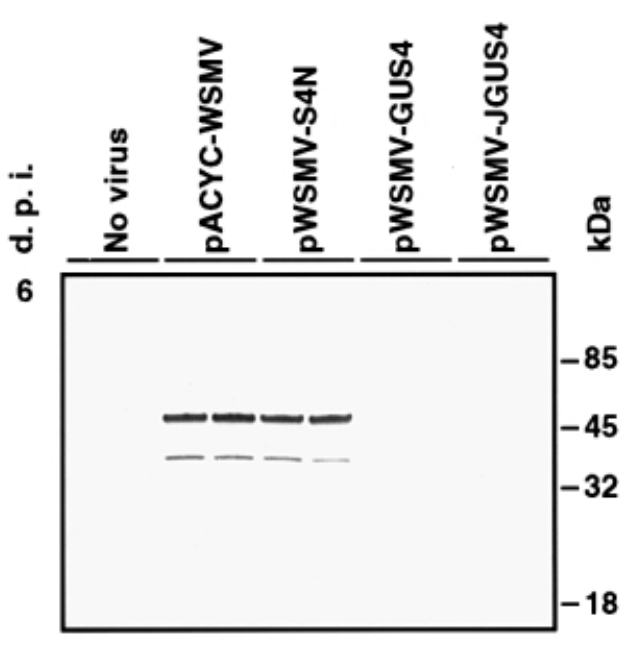

12

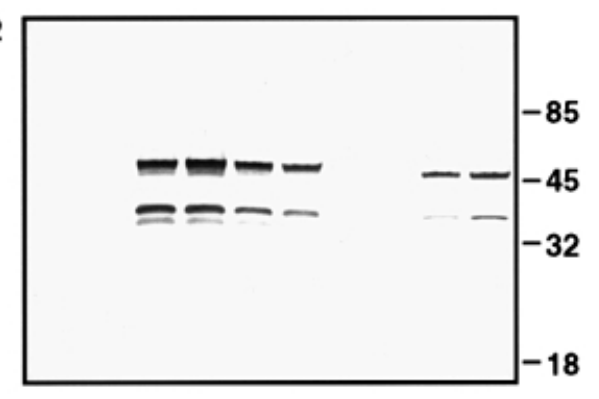

18

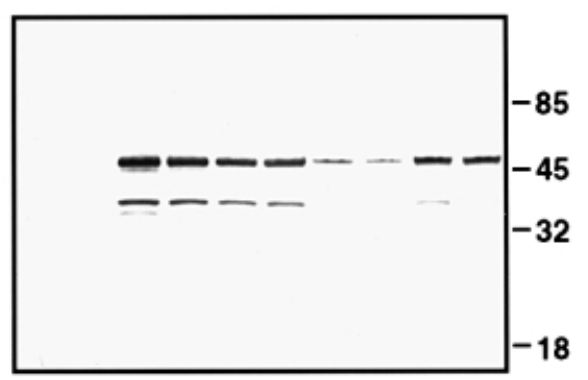

Figure 5. Analysis of wheat plants systemically infected with WSMV constructs bearing the GUS gene.

Wheat seedlings were inoculated with RNA transcribed from pWSMV-S4N (WSMV modified to contain a Sall site at the NIb-CP junction), pWSMV-GUS4 (WSMV bearing the GUS coding sequence inserted into pWSMV-S4N to produce an NIb-GUS fusion protein), or pWSMV-JGUS4 (WSMV bearing the GUS coding sequence flanked by Nla protease cleavage sites and inserted into pWSMV-S4N). (a) RT-PCR of RNA samples extracted from wheat plants 6,12 and 18 days post-inoculation (dpi). The GUS standard represents PCR product derived from pWSMV-JGUS4 plasmid DNA template, and the mobility of the expected full-length product is indicated with an arrow. The sizes (kbp) of $1 \mathrm{~kb}$ ladder DNA standards are indicated on the right. (b) Immunoblots of total soluble protein samples extracted from wheat plants at 6, 12 and $18 \mathrm{dpi}$ and probed with WSMV CP antibody. The sizes (kDa) and mobilities of protein standards are indicated on the right.

the GUS-bearing constructs at both 12 and $18 \mathrm{dpi}$ (Figure 5a), indicating spontaneous deletion of GUS sequences. The insertion of GUS sequences into the WSMV genome also affected CP expression (Figure 5b). Accumulation of CP in plants infected with either GUS construct was delayed and reduced, relative to wild-type virus or virus bearing only the Sall cloning site. Attenuation of $\mathrm{CP}$ accumulation was most pronounced when GUS was expressed as a fusion with the NIb protein.

\section{Expression of reporter genes in roots}

Roots from systemically infected wheat plants inoculated with pWSMV-JGUS4 or pWSMV-JNPT were evaluated for GUS or NPTII expression $12 \mathrm{dpi}$. GUS activity was discontinuous and confined primarily to the vascular bundle region of the root stele (Figure 6). GUS activity was absent from root epidermis and root hairs, and was rarely observed in the root cortex. GUS activity was 
(a)

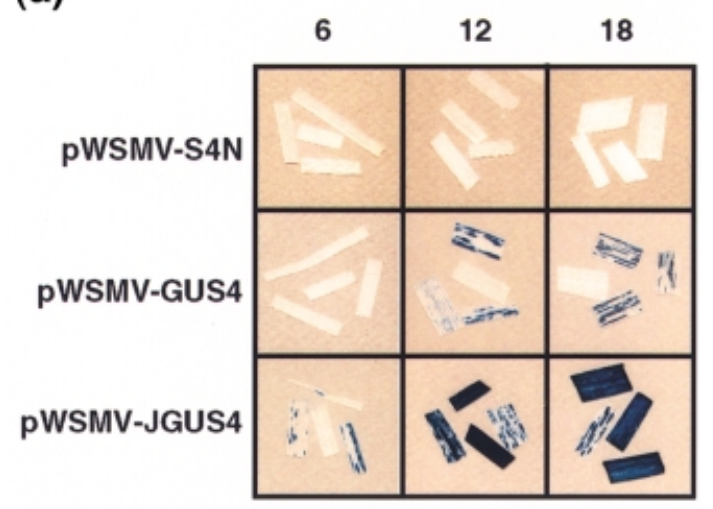

(b) pWSMV-JGUS4

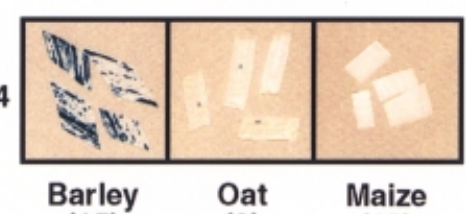

(15)

\section{d. p. i.}

12

(3)
(12)

Figure 4. Histochemical detection of GUS protein activity in leaves of cereal species.

The blue colour indicates tissues containing GUS activity. (a) The results of a time-course experiment in wheat assayed for GUS activity at 6,12 and 18 days post-inoculation. Wheat seedlings were inoculated with RNA transcribed from pACYC-WSMV (wild-type), pWSMV-S4N (WSMV modified to contain a Sall site at the NIb-CP junction), pWSMV-GUS4 (WSMV bearing the GUS coding sequence inserted into pWSMV-S4N to produce an NIb-GUS fusion protein) or pWSMV-JGUS4 (WSMV bearing the GUS coding sequence flanked by Nla protease cleavage sites and inserted into pWSMV-S4N). (b) GUS activity observed in other cereal species inoculated with RNA transcribed from pWSMV-JGUS4. The number in parentheses indicates sampling time (days post-inoculation).

particularly prominent in regions in close proximity to lateral root primordia, as observed for TEV (Dolja etal., 1992). Low levels of GUS activity were associated with tissues near the crown of the plant. NPTII was also expressed in roots. Although NPTII levels in roots (mean $507 \mathrm{ng} \mathrm{mg}^{-1}$ soluble protein) exceeded those observed in leaves (mean $298 \mathrm{ng} \mathrm{mg}^{-1}$ soluble protein) of the same plants (Table 1), soluble protein yields from roots were approximately $10 \%$ of those routinely recovered from leaves. Thus, on a fresh weight basis, more NPT II protein was present in leaves.

\section{Discussion}

Tolerance of foreign gene sequences by the WSMV genome

Our results indicate that choice of foreign sequence insertion site within the WSMV genome is an important consideration for expression vector development. Insertion of additional bases encoding a Sall site was tolerated

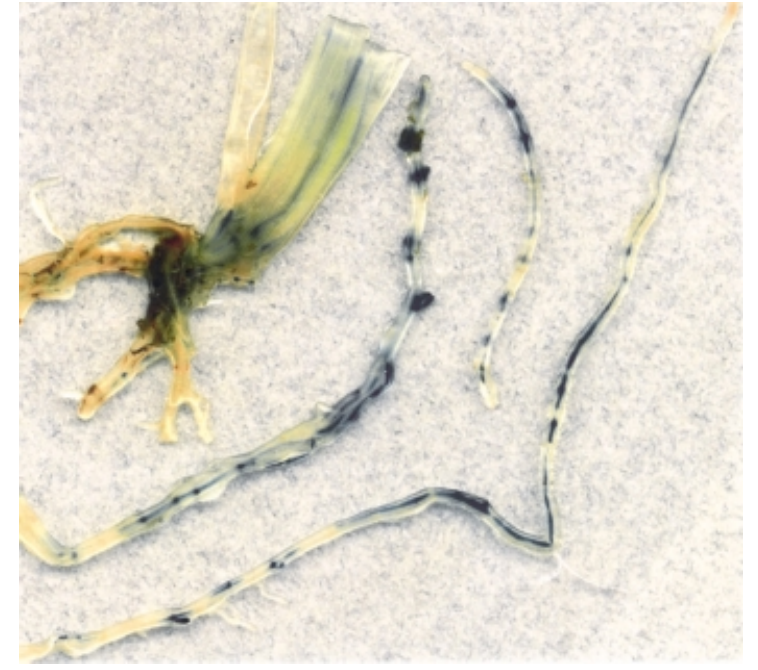

Figure 6. Histochemical detection of GUS protein activity in wheat roots and crown.

Wheat seedlings were inoculated with RNA transcribed from pWSMVJGUS4. Tissues were assayed at $12 \mathrm{dpi}$.

Table 1. NPT II accumulation ( $\mathrm{ng} \mathrm{mg}^{-1}$ soluble protein) in wheat tissues $12 \mathrm{dpi}$ with RNA transcribed from pWSMV-JNPT

\begin{tabular}{lllll}
\hline Tissue & $\begin{array}{l}\text { Non-inoculated } \\
\text { plant }\end{array}$ & $\begin{array}{l}\text { Inoculated } \\
\text { plant 1 }\end{array}$ & $\begin{array}{l}\text { Inoculated } \\
\text { plant 2 }\end{array}$ & $\begin{array}{l}\text { Inoculated } \\
\text { plant 3 }\end{array}$ \\
\hline Leaf & 7 & 208 & 233 & 452 \\
Root & 15 & 331 & 406 & 783 \\
\hline
\end{tabular}

at positions 1 and 2, but not position 3 (Figure 1a). Upon insertion of gene-length sequences, only position 2 yielded viable transcripts. The WSMV polyprotein contains at least six other proteolytic cleavage sites which could serve as additional locations for insertion of foreign sequences. It is possible that one or more of these other locations might express foreign genes more efficiently, but this requires further experimentation. The sequential pattern of proteolytic processing of the WSMV polyprotein is not yet known, and predicted cleavage sites have yet to be experimentally confirmed. Nevertheless, cleaved forms of NPT II and CP were produced from pWSMV-JNPT, implying that the amino acid motif 'OYCVYES' does in fact encompass the NIb-CP cleavage site.

Considerable host effects on foreign gene expression were also noted. This could be due to differences in a wide range of virus-host interactions, such as translational efficiency, rate of virus replication, or requirements for systemic virus spread, among many other possibilities. Host differences in foreign gene expression were more pronounced with the larger GUS gene than for the NPTII 
gene. Similarly, inserted NPTII sequences were more stable than GUS when expressed in wheat, the most permissive host found in this study.

\section{Potential uses and limitations of WSMV-based gene vectors}

We have demonstrated that the WSMV genome may be engineered to systemically express foreign genes in two major crop species, namely wheat and maize, as well as in two other cereals. As the host range of WSMV includes other monocotyledonous species, WSMV may prove useful as a gene vector in other grasses for which transformation protocols are lacking or poorly developed. However, given the differences in foreign gene expression and stability of different gene constructs in the same plant species, or the same gene construct in different species, the usefulness of WSMV as a gene vector will vary on a case by case basis. However, this is probably true for all RNA virus-based vector systems (Shivprasad et al., 1999).

The restriction of GUS activity to specific root tissues suggests that WSMV movement functions are unable to efficiently move the virus beyond the endodermis surrounding the vascular system. This implies that wheat roots have either structural or physiological mechanisms to prevent movement of WSMV in root tissues external to the stele. We have not yet examined whether WSMV, or gene expression vectors based on WSMV, infect floral tissues. However, as WSMV is only infrequently seedtransmitted (Hill etal., 1974), it is anticipated that WSMV gene vectors would not be suitable for ectopic expression of foreign genes in embryonic tissues.

The level of foreign gene expression obtained with the WSMV gene vector is similar to that reported for TEV, another potyviral gene expression vector (Dolja etal., 1998). In systemically infected wheat leaves, WSMV normally accumulates to about $75 \mu^{-1}$ g leaf tissue (White and Brakke, 1983) which might be considered the upper limit for gene expression with this vector. The amount of NPTII protein accumulating in wheat was substantial, approaching one-fifth of this maximum level. Nevertheless, viral vectors based on higher-titre viruses such as potato virus $\mathrm{X}$ or TMV clearly remain the systems of choice in cases where production of high concentrations of foreign proteins, or epitope-tagged virions, is required. However, if the goal is to produce useful levels of foreign proteins in graminacious hosts, the WSMV gene expression vector described here provides an effective new research tool. The WSMV-based vectors should be particularly useful for applications to determine the biological properties of foreign proteins by gain-of-function assays, without the need for plant transformation. It should also find utility in applying functional genomics approaches to cereals.

(c) Blackwell Science Ltd, The Plant Journal, (2000), 23, 547-555

\section{Experimental procedures}

\section{WSMV gene vector construction}

Six to 12 nucleotides containing the restriction cleavage site for Sall were inserted in different locations of the WSMV cDNA in pACYC-WSMV (Choi et al., 1999) by site-directed mutagenesis to create pWSMV-S1 (insertion of 5'-GACTCAGGTGTT-3' at nt 892), pWSMV-S4N (insertion of $5^{\prime}-$ GTCGAC- $3^{\prime}$ at nt 8168) and pWSMVS5N (insertion of $5^{\prime}$-GTCGACTCG-3' at nt 8192), respectively (Figure 1a). DNA fragments of the gene for $\beta$-glucuronidase (GUS) with flanking nucleotide sequences encoding seven amino acid residues (QYCVYES) consisting of the predicted Nla proteolytic cleavage site between NIb and CP at the $5^{\prime}$ end (JGUS) or the $3^{\prime}$ end (GUSJ), and the gene for neomycin phosphotransferase (NPTII) with the nucleotide sequence for the Nla proteolytic cleavage site at the $5^{\prime}$ end (JNPT) were produced by PCR using Pfu polymerase (Stratagene). For GUS, the following primers were used: primer GUS-5, 5'-CATCGTCGACTTACGTCCTGTAGAAACCCC-3' and primer GUS-3, 5'-CTCTGTCGACTTGTTTGCCTCCCTGCTGC- $3^{\prime}$. For GUS plus $5^{\prime}$ proximal sequences encoding the proteinase cleavage site, primer JGUS-5, 5'CATCGTCGACCAGTATTGTGTATACGAGTCATTACGTCCTGTAGAAACCCC-3' and primer GUS-3 were used. For GUS plus $3^{\prime}$ proximal sequences encoding the proteinase cleavage site, primer GUS-5 and primer GUSJ-3, 5'-CCTCGTCGACTGACTCGTATACACAATATTGTTTGCCTCCCTGC TGC-3' were used. For NPTII, primers JNPT-5 (5'-GAGAGTCGACCAATACTGCGTGTACGAATCGGGGATTGAA CAAGATGGA-3') and NPT-3 (5'GAGAGTCGACGGGATTGAACAAGATGGA-3') were used. The DNA fragments produced by PCR were digested with Sall and inserted into the engineered Sall sites of pWSMV-S1 or pWSMVS4N to obtain pWSMV-GUS1, pWSMV-GUSJ1, pWSMV-GUS4, pWSMV-JGUS4 and pWSMV-JNPT, respectively (Figure 1b).

\section{Inoculation of plants with in vitro transcripts}

Plasmid templates ( $12.5 \mu \mathrm{g}$ per reaction) for in vitro transcription were linearized with Notl and transcribed in the presence or absence of $1 \mathrm{mM}$ cap analogue $\left[\mathrm{m} 7 \mathrm{G}\left(5^{\prime}\right) \mathrm{ppp}\left(5^{\prime}\right) \mathrm{G}\right]$ using the SP6 MAXIscript kit (Ambion) in a total volume of $250 \mu \mathrm{l}$ as recommended by the manufacturer. An equal volume of $2 \%$ sodium pyrophosphate containing $2 \mathrm{mg} \mathrm{ml}^{-1}$ of bentonite was added to the in vitro transcription products and the mixture was inoculated onto 15-20 plants with celite added as an abrasive.

\section{$R T-P C R$}

RT-PCR was performed to verify virus replication. Total nucleic acids were extracted from younger, non-inoculated leaf tissue $(0.2 \mathrm{~g})$ as described previously (Choi et al., 1999). After reverse transcription using an oligo(dT) primer, 30 PCR cycles were performed with primers flanking the WSMV CP gene (CP1a, $5^{\prime}$ AGCTTATGAGCGCTATTATTGCAGCAT-3' and CP2, 5'-CGATTTTTTTTTTTTTTTGCCGTCGCCCT-3'). PCR for specific amplification of the GUS gene employed primers GUS-5 and GUS-3. PCR products were analysed on $1 \%$ agarose gels.

\section{Immunological detection of CP and NPT II}

Proteins were extracted from leaf or root tissues by homogenization with $7 \mathrm{vol} 0.25 \mathrm{M}$ Tris- $\mathrm{HCl}(\mathrm{pH} 7.8)$ containing $1 \mathrm{mM}$ phenylmethylsulphonylfluoride. Homogenates were centrifuged at 
$7500 \mathrm{~g}$ for $30 \mathrm{~min}$, and supernatants were analysed. Protein samples were mixed with $2 \times$ loading buffer $(0.2 \%$ bromophenol blue, $100 \mathrm{~mm}$ Tris- $\mathrm{HCl}, \mathrm{pH} \mathrm{6.8,} 200 \mathrm{~mm}$ dithiothreitol, 4\% SDS and $20 \%$ glycerol) and denatured by boiling for $3 \mathrm{~min}$ before loading on $12 \%$ polyacrylamide gels. Approximately $20 \mu \mathrm{g}$ of total soluble proteins were used for immunoblot analyses with antibodies for CP (Brakke etal., 1990) or NPTII (Eppendorf-5 Prime, Boulder, Colorado, USA). Enzyme-linked immunosorbent assay (ELISA) of NPT II employed the NPTII ELISA kit (Eppendorf-5 Prime) as per the manufacturer's recommendations.

\section{Histochemical detection of GUS}

Leaf or root tissues were cut into small pieces and fixed for $30 \mathrm{~min}$ by vacuum infiltration in $0.7 \%$ formaldehyde. Fixed tissues were rinsed five times for $15 \mathrm{~min}$ with distilled water. The tissues were immersed in $50 \mathrm{~mm}$ phosphate buffer (pH 7.0) containing $2 \mathrm{mM} \mathrm{5-}$ bromo-4-chloro-3-indolyl glucuronide (X-gluc), and incubated at $37^{\circ} \mathrm{C}$ for up to $12 \mathrm{~h}$. The tissues were then clarified with $70 \%$ ethanol and finally with $5 \%$ sodium hypochlorite.

\section{Acknowledgements}

We thank Jeffrey S. Hall for excellent technical assistance and Martin Dickman, Les Lane and Michael Edwards for helpful comments. This work was partially supported by funding from the University of Nebraska Center for Biotechnology to T.J.M. and I.-R.C. Mention of proprietary or brand names are necessary to report factually on available data; however, the USDA neither guarantees nor warrants the standard of the product, and the use of the name by USDA implies no approval to the exclusion of other products that may also be suitable. This article is in the public domain and not copyrightable. It may be freely reprinted with customary crediting of source.

\section{References}

Angell, S.M. and Baulcombe, D.C. (1995) Cell-to-cell movement of potato virus $X$ revealed by microinjection of a viral vector tagged with the $\beta$-glucuronidase gene. Plant J. 7, 135-140.

Angell, S.M. and Baulcombe, D.C. (1999) Potato virus X ampliconmediated silencing of nuclear genes. Plant J. 20, 357-362.

Baulcombe, D.C. (1999) Fast forward genetics based on virusinduced gene silencing. Curr. Opin. Plant Biol. 2, 109-113.

Baulcombe, D.C., Manoussopoulos, I.N., Roberts, I.M. and Harrison, B.D. (1993) Signal for potyvirus-dependent aphid transmission of potato aucuba mosaic virus and the effect of its transfer to potato virus X. J. Gen. Virol. 74, 1245-1253.

Baulcombe, D.C., Chapman, S. and Santa Cruz, S. (1995) Jellyfish green fluorescent protein as a reporter for virus infections. Plant J. 7, 1045-1053.

Brakke, M.K., Skopp, R.N. and Lane, L.C. (1990) Degradation of the wheat streak mosaic virus capsid protein during leaf senescence. Phytopathology, 80, 1401-1405.

Casper, S.J. and Holt, C.A. (1996) Expression of the green fluorescent protein-encoding gene from a tobacco mosaic virus-based vector. Gene, 173, 69-73.

Chapman, S., Kavanagh, T. and Baulcombe, D. (1992) Potato virus $X$ as a vector for gene expression in plants. Plant J. 2, 549557.

Choi, I.-R., French, R., Hein, G.L. and Stenger, D.C. (1999) Fully biologically active in vitro transcripts of the eriophyid mite- transmitted wheat streak mosaic tritimovirus. Phytopathology, 89, 1182-1185.

Culver, J.N., Lehto, K., Close, S.M., Hilf, M.E. and Dawson, W.O. (1993) Genomic position affects the expression of tobacco mosaic virus movement and coat protein genes. Proc. Natl Acad. Sci. USA, 90, 2055-2059.

Dawson, W.O., Lewandowski, D.J., Hilf, M.E., Bubrick, P., Raffo, A.J., Shaw, J.J., Grantham, G.L. and Desjardins, P.R. (1989) A tobacco mosaic virus-hybrid expresses and loses an added gene. Virology, 172, 285-292.

De Zoeten, G.A., Penswick, J.R., Horisberger, M.A., Ahl, P., Schultze, M. and Hohn, T. (1989) The expression, localization, and effect of a human interferon in plants. Virology, 172, 213-222.

Dolja, V.V., McBride, H.J. and Carrington, J.C. (1992) Tagging of plant potyvirus replication and movement by insertion of $\beta$ glucuronidase into the viral polyprotein. Proc. Natl Acad. Sci. USA, 89, 10208-10212.

Dolja, V.V., Hong, J., Keller, K.E., Martin, R.R. and Peremyslov, V.V. (1997) Suppression of potyvirus infection by coexpressed closterovirus protein. Virology, 234, 243-252.

Dolja, V.V., Peremyslov, V.V., Keller, K.E., Martin, R.R. and Hong, J. (1998) Isolation and stability of histidine-tagged proteins produced in plants via potyvirus gene vectors. Virology, 252, 269-274.

Donson, J., Kearney, C.M., Hilf, M.E. and Dawson, W.O. (1991) Systemic expression of a bacterial gene by a tobacco mosaic virus-based vector. Proc. Natl Acad. Sci. USA, 88, 7204-7208.

Fitchen, J., Beachy, R.N. and Hein, M.B. (1995) Plant virus expressing hybrid coat protein with added murine epitope elicits autoantibody response. Vaccine, 13, 1051-1057.

French, R., Janda, M. and Ahlquist, P. (1986) Bacterial gene inserted in an engineered RNA virus: efficient expression in monocotyledonous plant cells. Science, 231, 1294-1297.

Hamamoto, H., Sugiyama, Y., Nakagawa, N., Hasida, E., Matsunaga, Y., Takemoto, S., Watanabe, Y. and Okada, Y. (1993) A new tobacco mosaic virus vector and its use for the systemic production of angiotensin-l-converting enzyme inhibitor in transgenic tobacco and tomato. Bio-Technology, 11, 930-932.

Hammond-Kosack, K.E., Staskawicz, B.J., Jones, J.D.G. and Baulcombe, D.C. (1995) Functional expression of a fungal avirulence gene from a modified potato virus $X$ genome. Mol. Plant-Microbe Interact. 8, 181-185.

Hill, J.H., Martinson, C.A. and Russell, W.A. (1974) Seed transmission of maize dwarf mosaic and wheat streak mosaic viruses in maize and response of inbred lines. Crop Sci. 14, 232-235.

Joelson, T., Åkerblom, L., Oxelfelt, P., Strandberg, B., Tomenius, K. and Morris, T.J. (1997) Presentation of a foreign viral peptide on the surface of tomato bushy stunt virus. J. Gen. Virol. 78, 1213-1217.

Joshi, R.L., Joshi, V. and Ow, D.W. (1990) BSMV genome mediated expression of a foreign gene in dicot and monocot plant cells. EMBO J. 9, 2663-2669.

Karrer, E.E., Beachy, R.N. and Holt, C.A. (1998) Cloning of tobacco genes that elicit the hypersensitive response. Plant Mol. Biol. 36, 681-690.

Kearney, C.M., Donson, J., Jones, G.E. and Dawson, W.O. (1993) Low level genetic drift in foreign sequences replicating in an RNA virus in plants. Virology, 192, 11-17.

Koo, M., Bendahmane, M., Lettieri, G.A., Paoletti, A.D., Lane, T.E., Fitchen, J.H., Buchmeier, M.J. and Beachy, R.N. (1999) Protective immunity against murine hepatitis virus (MHV) 
induced by intranasal or subcutaneous administration of hybrids of tobacco mosaic virus that carries an MHV epitope. Proc. Natl Acad. Sci. USA, 96, 7774-7779.

Kumagi, M.H., Turpen, T.H., Weinzettl, N. et al. (1993) Rapid, highlevel expression of biologically active a-trichosanthin in transfected plants by an RNA viral vector. Proc. Natl Acad. Sci. USA, 90, 427-430.

Kumagi, M.H., Donson, J., Della-Cioppa, G., Hanley, H.K. and Grill, L.K. (1995) Cytoplasmic inhibition of carotenoid biosynthesis with virus-derived RNA. Proc. Natl Acad. Sci. USA, 92, 16791683.

Kumagi, M.H., Keller, Y., Bouvier, F., Clary, D. and Camara, B. (1998) Functional integration of non-native carotenoids into chloroplasts by viral-derived expression of capsanthincapsorubin synthase in Nicotiana benthamiana. Plant J. 14, 305-315.

Laufs, J., Wirtz, U., Kammann, M., Matzeit, V., Scaefer, S., Schell, J., Czernilofsky, A.P., Baker, B. and Gronenborn, B. (1990) Wheat dwarf virus Ac/Ds vectors: expression and excision of transposable elements introduced into various cereals by a viral replicon. Proc. Natl Acad. Sci. USA, 87, 7752-7756.

Lazarowitz, S.G., Pinder, A.J., Damsteegt, V.D. and Rogers, S.G. (1989) Maize streak virus genes essential for systemic spread and symptom development. EMBO J. 8, 1023-1032.

Lin, N.-S., Lee, Y.-S., Lin, B.-Y., Lee, C.-W. and Hau, Y.-H. (1996) The open reading frame of bamboo mosaic potexvirus satellite RNA is not essential for its replication and can be replaced with a bacterial gene. Proc. Natl Acad. Sci. USA, 93, 3138-3142.

McCormick, A.A., Kumagi, M.H., Hanley, K., Turpen, T.H., Hakim, I., Grill, L.K., Tuse, D., Levy, S. and Levy, R. (1999) Rapid production of specific vaccines for lymphoma by expression of the tumor-derived single chain $\mathrm{Fv}$ epitopes in tobacco plants. Proc. Natl Acad. Sci. USA, 96, 703-708.

Matzeit, V., Schaefer, S., Kammann, M., Schalk, H.J., Schell, J. and Gronenborn, B. (1991) Wheat dwarf virus vectors replicate and express foreign genes in cells of monocotyledonous plants. Plant Cell, 3, 247-258.

Palmer, K.E., Thomson, J.A. and Rybicki, E.P. (1999) Generation of maize cell lines containing autonomously replicating maize streak virus-based gene vectors. Arch. Virol. 144, 1345-1360.

Porta, C., Spall, V.E., Loveland, J., Johnson, J.E., Barker, P.J. and Lomonossoff, G.P. (1994) Development of cowpea mosaic virus as a high-yield system for the presentation of foreign peptides. Virology, 202, 949-955.

Rommens, C.M.T., Salmeron, J.M., Baulcombe, D.C. and Staskawicz, B.J. (1995) Use of a gene expression system based on potato virus $\mathrm{X}$ to rapidly identify and characterize a tomato Pto homolog that controls fenthion sensitivity. Plant Cell, 7, 249-257.

Ruiz, M.T., Voinnet, O. and Baulcombe, D.C. (1998) Initiation and maintenance of virus-induced gene silencing. Plant Cell, 10, 937-946.

Ryabov, E.V., Oparka, K.J., Santa Cruz, S., Robinson, D.J. and Taliansky, M.E. (1998) Intracellular location of two groundnut rosette umbravirus proteins delivered by PVX and TMV vectors. Virology, 242, 303-313.

Scholthof, H.B., Morris, T.J. and Jackson, A.O. (1993) The capsid protein gene of tomato bushy stunt virus is dispensable for systemic movement and can be replaced for localized expression of foreign genes. Mol. Plant-Microbe Interact. 6, 309-322.

Scholthof, H.B., Scholthof, K.-B.G. and Jackson, A.O. (1995) Identification of tomato bushy stunt virus host-specific symptom determinant by expression of individual genes from a potato virus $\mathrm{X}$ vector. Plant Cell, 7, 1157-1172.

Shen, W.-H. and Hohn, B. (1994) Amplification of the $\beta$ glucuronidase gene in maize plants by vectors based on maize streak virus. Plant J. 5, 227-236.

Shen, W.-H. and Hohn, B. (1995) Vectors based on maize streak virus can replicate to high copy numbers in maize plants. $J$. Gen. Virol. 76, 965-969.

Shivprasad, S., Pogue, G.P., Lewandowski, D.J., Hidalgo, J., Donson, J., Grill, L.K. and Dawson, W.O. (1999) Heterologous sequences greatly affect foreign gene expression in tobacco mosaic virus-based vectors. Virology, 255, 312-323.

Stenger, D.C., Hall, J.S., Choi, I.-R. and French, R. (1998) Phylogenetic relationships within the family Potyviridae: wheat streak mosaic virus and brome streak mosaic virus are not members of the genus Rymovirus. Phytopathology, 88, 782-787.

Sugiyama, Y., Mamamoto, H., Takemoto, S. and Watanabe, Y. (1995) Systemic production of foreign peptides on the particle surface of tobacco mosaic virus. FEBS Lett. 359, 247-250.

Takamatsu, N., Watanabe, Y., Tanagi, H., Meshi, T., Shiba, T. and Okada, Y. (1990) Production of enkephalin in tobacco protoplasts using tobacco mosaic virus RNA vector. FEBS Lett. 269, 73-76.

Timmermans, M.C., Das, O.P. and Messing, J. (1992) Trans replication and high copy numbers of wheat dwarf virus vectors in maize cells. Nucl. Acids Res. 20, 4047-4054.

Tobais, C.M., Oldroyd, G.E., Chang, J.H. and Staskawicz, B.J. (1999) Plants expressing the Pto disease resistance gene confer resistance to recombinant $\mathrm{PVX}$ containing the avirulence gene AvrPto. Plant J. 17, 41-50.

Turpen, T.H., Reinl, S.J., Charoenvit, Y., Hoffman, S.L., Fallarme, V. and Grill, L.K. (1995) Malarial epitopes expressed on the surface of recombinant tobacco mosaic virus. Bio-Technology, 13, 53-57.

Ugaki, M., Ueda, T., Timmermans, M.C., Vieira, J., Elliston, K.O. and Messing, J. (1991) Replication of a geminivirus derived shuttle vector in maize endosperm cells. Nucl. Acids Res. 19, 371-377.

Usha, R., Rohll, J.B., Spall, V.E., Shanks, M., Maule, A.J., Johnson, J.E. and Lomonossoff, G.P. (1993) Expression of an animal virus antigenic site on the surface of a plant virus particle. Virology, 197, 366-374.

Verch, T., Yusibov, V. and Koprowski, H. (1998) Expression and assembly of a full-length monoclonal antibody in plants using a plant virus vector. J. Immunol. Methods, 220, 26-75.

White, J.L. and Brakke, M.K. (1983) Protein changes in wheat infected with wheat streak mosaic virus and in barley infected with barley stripe mosaic virus. Physiol. Plant Pathol. 22, 87-100.

Whitham, S.A., Yamamoto, M.L. and Carrington, J.C. (1999) Selectable viruses and altered susceptibility mutants in Arabidopsis thaliana. Proc. Natl Acad. Sci. USA, 96, 772-777.

Wigdorovitz, A., Pérez Filgueira, D.M., Robertson, N., Carrillo, C., Sadir, A.M., Morris, J. and Borca, M.V. (1999) Protection of mice against the challenge with foot and mouth disease virus (FMDV) by immunization with foliar extracts from plants infected with recombinant tobacco mosaic virus expressing the FMDV structural protein VP1. Virology, 264, 85-91.

Yusibov, V., Modleska, A., Steplewski, K., Agadjanyan, M., Weiner, D., Hooper, D.C. and Koprowski, H. (1997) Antigens produced in plants by infection with chimeric plant viruses immunize against rabies virus and HIV-1. Proc. Natl Acad. Sci. USA, 94, 5784-5788. 